\title{
12 Chinese Development Aid in Africa
}

What, where, why, and how much?

Deborah Brautigam

\section{Introduction}

China's development aid to Africa has increased rapidly, yet this might be the only fact on which we have widespread agreement when it comes to Chinese aid. ${ }^{1}$ Analysts disagree about the nature of China's official development aid, the countries that are its main recipients, the reasons for providing aid, the quantity of official aid, and its impact. Why does this matter? Knowing more about Chinese development aid is important for understanding Chinese foreign policy and economic statecraft: how and to what ends does China use its government policy tools? It is also important for more accurate comparisons between Chinese practices and those of other donors and providers of finance. Finally, for those who are interested in the question of whether, as it rises, China will transform, reform or maintain the existing system of norms and rules (Kim 1999), development aid provides a particularly interesting case study. The rules and norms about foreign aid have been forged not by a global institution, but primarily by the Development Assistance Committee (DAC) of the Organisation for Economic Cooperation and Development (OECD) - a group of countries of which China is not a part. To answer questions about China's impact on these rules and norms, we need to have a sound idea of what China is actually doing as a donor.

This chapter is organised as follows: the first section begins by briefly explaining the various categories of official finance used by the OECD in order to establish a common language for discussing Chinese finance in Africa. It then introduces the variety of instruments used by the Chinese for official finance, and explains why only a small proportion of Chinese finance in Africa is equivalent to official development aid. Next is a comparison of the quantity of official development aid from China and from some of the 24 members of the OECD's DAC, and a discussion of two recent cases to illustrate the difference between development aid and other official tools of economic diplomacy. Finally, the chapter argues that several recent efforts to estimate Chinese 'aid' and to analyse it using proxy figures are misguided and have produced misleading results.

\section{What aid is (and is not)}

As Figure 13.1 illustrates, the international financial architecture is made up of many different kinds of flows. The two that are relevant for our purposes are 'official development assistance' and 'other official flows'. This chapter uses the standardised definition of official development assistance (ODA) agreed upon in 1972 by the members of the DAC: concessional funding given to developing countries (those with a per capita income below 
a regularly adjusted threshold) and to multilateral institutions primarily for the purpose of promoting welfare and economic development in the recipient country (OECD 2008). Funding must be 'concessional in character' (that is, it must involve some genuine subsidy from the government) and loans must have a grant element of at least 25 per cent using a 10 per cent discount rate. While only concessional loans and grants may qualify as ODA, governments also offer other official flows: funds for firms from the donor country to subsidise or guarantee their firms' private investment in recipient countries, military aid, and export credits (OECD 2008a, 2010). These funds are reported as 'other official flows' or OOF. The OOF category includes loans that are not concessional in character, or those with a grant element of less than 25 per cent, and 'official bilateral transactions, whatever their grant element, that are primarily export facilitating in purpose. This category includes by definition export credits' (OECD n.d., emphasis added).

Figure 13.1 Global development finance

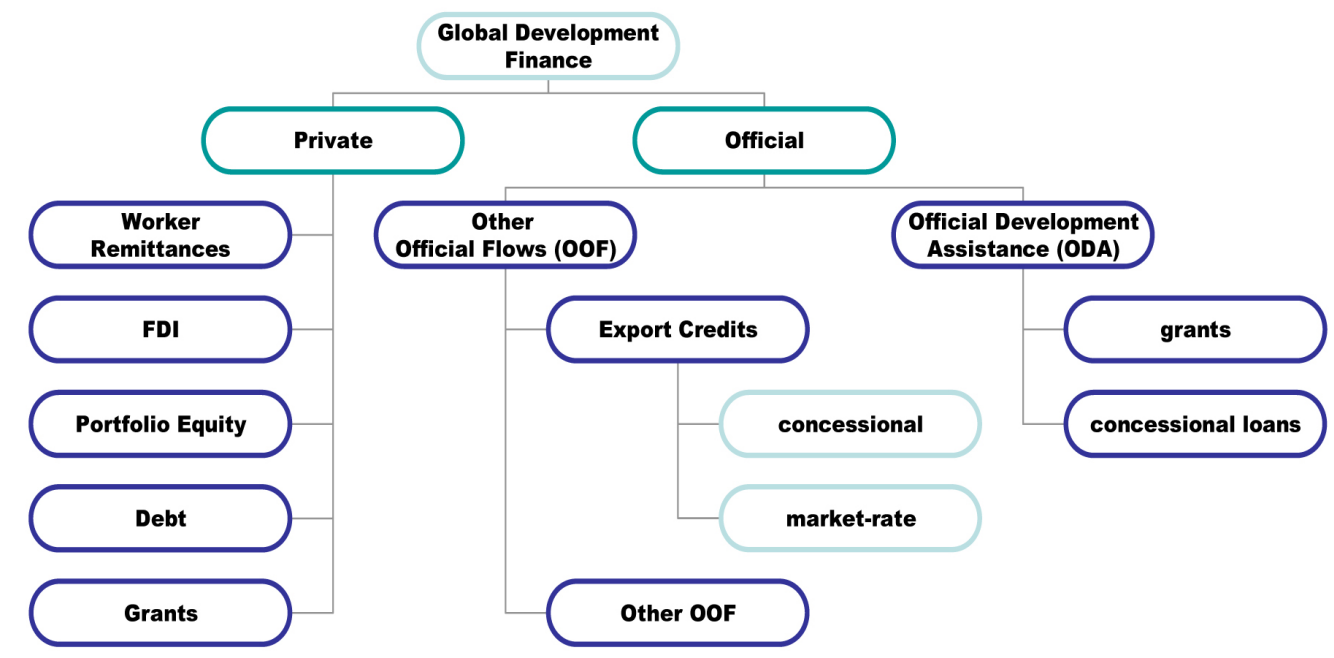

China provides the equivalent of ODA through three instruments: grants, zerointerest loans, and concessional (fixed-rate, low-interest) loans. These instruments finance Chinese Government scholarships for African students (about 5500 students per annum); Chinese medical teams; 'turn-key' construction of stadiums, government buildings, telecommunications networks and other infrastructure; technical assistance teams in agriculture and other sectors; short-term training programs; youth volunteers; and material aid (export of Chinese goods).

Although China's Ministry of Commerce is responsible for China's grants and zerointerest loans, China Eximbank and China Development Bank provide the bulk of Chinese overseas finance. These two policy banks, established in 1994, operate as part of Beijing's portfolio of instruments to support China's own development goals. While China Eximbank manages one of China's aid instruments (concessional loans), this is a very small part of the bank's portfolio. In its 2006 review of China Eximbank, a credit rating agency pointed out 
that concessional loans at the end of 2005 made up only 3 per cent of China Eximbank's assets (Standard \& Poor's 2006). China Development Bank does not offer concessional loans, and their interest rates tend to be higher than those offered by China Eximbank.

For Africa, the category of 'other official flows' provided by OECD members has normally been well below the level of funds provided on ODA terms. This is not the case, however, for China. China's government-provided finance to Africa falls primarily into the category of other official flows, not ODA. This is particularly true of funds coming from China's policy banks. We turn now to a closer look at Chinese official finance in Africa.

\section{China's official finance in Africa: what instruments?}

As noted above, China's official finance in Africa consists of grants, zero-interest loans, debt relief, and concessional loans (which would all qualify as ODA) as well as preferential export credits, market-rate export buyers' credits, and commercial loans from Chinese banks, none of which would qualify as ODA. China also provides equity funds that assist Chinese companies investing in Africa through the China-Africa Development Fund, and has established a fund to on-lend up to US\$1 billion to African small and medium enterprises (SMEs) through local African banks. While the China-Africa Development Fund, as support for China's own companies, does not qualify as ODA, the finance for SMEs could qualify if it was provided on the appropriate concessional terms.

\section{ODA: grants, zero-interest loans and debt relief}

Grants and zero-interest loans were the primary instruments of China's official development aid until 1995 when concessional loans were introduced. In April 2011, the Chinese State Council released its first white paper on foreign aid (State Council 2011). According to this report, approximately 40 per cent of China's aid has been financed through grants. (These grants are, however, rarely given as budget support.) Zero-interest loans are also a mainstay of China's aid. The debt relief program launched by Beijing in 2000 targeted overdue zero-interest loans for cancellation, with RMB25.58 billion (US\$3.76 billion) having been cancelled, and of this, RMB18.96 billion (US\$2.79 billion) was cancelled in Africa (State Council 2011). While debt relief does qualify as ODA, if the cancelled debt was originally given as a foreign aid loan (as opposed to an export credit or other non-ODA debt) it cannot be double-counted as new ODA.

\section{ODA: concessional loans}

Only larger projects (minimum size of RMB20 million, or about US\$2.4 million) that involve considerable use of Chinese goods (at least 50 per cent) and services (that is, Chinese construction firms as contractors) may be funded with concessional loans. As of the end of 2009, China had 'provided' (almost certainly, committed) approximately US $\$ 10.8$ billion in concessional loans since the inception of that program in 1995- 'to 76 foreign countries, supporting 325 projects, of which 142 had been completed' (State Council 2011:5). This number reflects the sharp increase in concessional loan-supported projects, with 56 per cent still being implemented or in the planning stage. (It also shows why the figures for commitment of concessional loans are far higher than those for actual disbursement.) 
The percentage for Africa was not given, but the report supplied information on sectors: 61 per cent went for economic infrastructure, industry secured 16 per cent, and energy and resource development accounted for 9 per cent (State Council 2011:6).

China's concessional loan program in Africa has grown rapidly. At the end of 2005, China Eximbank had cumulatively funded only about US\$800 million in concessional loans in Africa, for 55 projects (Broadman 2006). Two years later, the number of African projects had risen to 87 , and the cumulative value was about US $\$ 1.5$ billion. At the end of 2006, Chinese leaders announced that China Eximbank would make US $\$ 2$ billion in concessional loans and US\$3 billion in preferential export credits available in Africa between 2007 and 2009. Three years later, after announcing that this target had been met, a new pledge of US\$10 billion in concessional/preferential credits was announced for Africa, to be committed over the next three years - that is, by 2012.

China also supplies other official funds that do not meet the requirements for ODA. Three categories of loans are relevant here: export buyers' credits (including preferential buyers' credits), official loans at commercial rates, and strategic lines of credit to Chinese companies. Both China Eximbank and China Development Bank offer official loans at commercial rates, and both allow export financing.

\section{OOF: export buyers' credits}

China Eximbank offers short-term credits to Chinese exporters (export sellers' credits) to help them finance foreign sales, and it offers longer-term credits to foreign buyers to assist in the export of Chinese goods and services. A small proportion of the export buyers' credits are offered at preferential rates, usually with a fixed interest rate of 2 or 3 per cent. As export credits, these loans do not qualify as ODA, although in structure they are very similar to the concessional loan instrument offered by Eximbank. Most long-term credits are, however, issued at London Interbank offered rate (LIBOR)-plus rates. The lowest rate of credit for which information is publicly available was issued at LIBOR plus 1 per cent (100 basis points). In 2007, Li Ruogu, the President of China Eximbank, announced that his bank expected to commit approximately US\$20 billion in loans within Africa over the next three years. This appears to have been done.

\section{OOF: official loans at commercial rates}

China Development Bank (CDB) also offers policy loans at competitive rates. Traditionally, CDB operated primarily inside China, but in recent years it has begun to expand overseas. As of March 2007, CDB reported that it had financed 30 projects in Africa, for a total of about US $\$ 1$ billion (Xinhua, 14 May 2007). Three and a half years later, a bank official interviewed by Xinhua announced that as of September 2010, it had committed more than US $\$ 10$ billion to projects in Africa and disbursed 'USD5.6 billion in financing to 35 projects across over 30 African nations' (People's Daily, 17 November 2010). This also reflects rapid expansion (and, given the number of projects in 2010, suggests that the 2007 figures refer to commitments rather than disbursements). According to the 2010 interview, the largest 
proportion of the loans issued so far has gone to South Africa, Angola and Botswana. China Development Bank does not provide official development aid; it issues commercial loans based on LIBOR plus a margin - usually at least 200 basis points.

\section{Strategic lines of credit and suppliers' credits}

China's policy banks have another tool in their portfolio: strategic lines of credit offered to China's 'dragon-head' companies-firms the Government believes have the potential to become competitive multinationals. In March 2009, for example, CDB extended a US $\$ 15$ billion financing package to support the telecommunications firm ZTE in its overseas business, while two months later Eximbank concluded a line of credit for ZTE worth US $\$ 10$ billion. ZTE's rival Huawei benefited from a US\$30 billion strategic package from CDB.

These strategic lines of credit create a financing platform that combines export sellers' credits, export buyers' credits, import credits (allowing the company to finance imports of foreign technologies), and preferential foreign loans, all of which allow the company to secure foreign business - often through direct offers of vendor finance to the purchaser. In Ethiopia, for example, ZTE was able to offer finance for the Ethiopian Government's Millennium Telecoms project, securing a US\$1.5 billion deal for which the interest rate was LIBOR plus 150 basis points (Personal communication, 2011). Huawei offered a Brazilian firm financing at LIBOR plus 200 basis points, with a two-year grace period (Bloomberg 2011). As with the other forms of non-concessional official finance, these strategic lines of credit are clearly not ODA.

\section{Chinese aid in Africa: where and how much?}

China's first official white paper on foreign aid discussed only those Chinese aid instruments that most closely resemble official development assistance. 'By the end of 2009', the paper stated, 'China had provided a total of 256.29 billion yuan [US\$37.7 billion] in aid to foreign countries, including 106.2 billion yuan [US\$15.6 billion] in grants, 76.54 billion yuan [US\$11.3 billion] in interest-free loans and 73.55 billion yuan [US\$10.8 billion] in concessional loans'. It also revealed that aid had grown by 29.4 per cent annually between 2004 and 2009 (State Council 2011:3). ${ }^{2}$ Although the information appears thin, this was the first time the Chinese Government had been this transparent about its aid figures and the first time figures had been included on loans, grants and concessional loans. For the fiscal year 2009 alone, nearly half (46.7 per cent) of Chinese aid was committed to Africa (State Council 2011:12). These figures follow other announcements made in earlier years by Chinese leaders (Table 13.1). 
Table 13.1 Announcements of aid by Chinese leaders

\begin{tabular}{|l|l|l|c|c|}
\hline \multirow{2}{*}{ Date } & \multirow{2}{*}{ Leader } & Type of aid & \multicolumn{2}{|c|}{ Amounts } \\
\cline { 4 - 5 } & & & RMB & US\$ \\
\hline 2008 & Premier Wen Jiabao & Africa grants in 2007 & 2.377 billion & 313 million \\
\hline & & Africa zero-interest loans in 2007 & 700 million & 92 million \\
\hline & & Africa concessional loans & n.a. & n.a. \\
\hline & & Total Africa aid, 1950-2006 & 44 billion & 5.8 billion \\
\hline & & Total aid, 1950-2006 & 206.5 billion & 27 billion \\
\hline & & Of which grants & 90.8 billion & 12 billion \\
\hline 2011 & State Council & Of which 'loans' & 115.7 billion & 15.2 billion \\
\hline & & Total aid, 1950-2009 & & \\
\hline & & Of which grants & 106.2 billion & 15.6 billion \\
\hline & & Of which zero-interest loans & 76.54 billion & 11.25 billion \\
\hline & & Of which concessional loans & 73.55 billion & 10.8 billion \\
\hline
\end{tabular}

n.a. not applicable

Note: Conversions made from RMB to US dollars at a rate of RMB7.6 = US $\$ 1$ for 2006 and 2007 figures, and RMB6.8 = US $\$ 1$ for 2009 figures. Figures are gross commitments and do not include debt relief.

Sources: Brautigam (2011); State Council (2011).

Within Africa, where does this aid go? Figure 13.2 provides part of the story. The white squares are years in which an African country had diplomatic ties with Taiwan, while the grey squares represent years of diplomatic ties with Beijing. As we can see here, Chinese aid agreements follow diplomatic ties. All countries in sub-Saharan Africa with which Beijing has diplomatic ties receive foreign aid from China, even if (as in South Africa) it is symbolic, such as the building of a pair of primary schools. Furthermore, ODA does not appear to be given in larger amounts to resource-rich countries, as we will see with Nigeria and the Democratic Republic of Congo (DRC) below. Grants and zero-interest loans are distributed fairly evenly around the continent, while concessional loans fit a country's ability to pay, either because it is middle income (Mauritius, Namibia, Botswana) or because it will finance an income-generating project. 


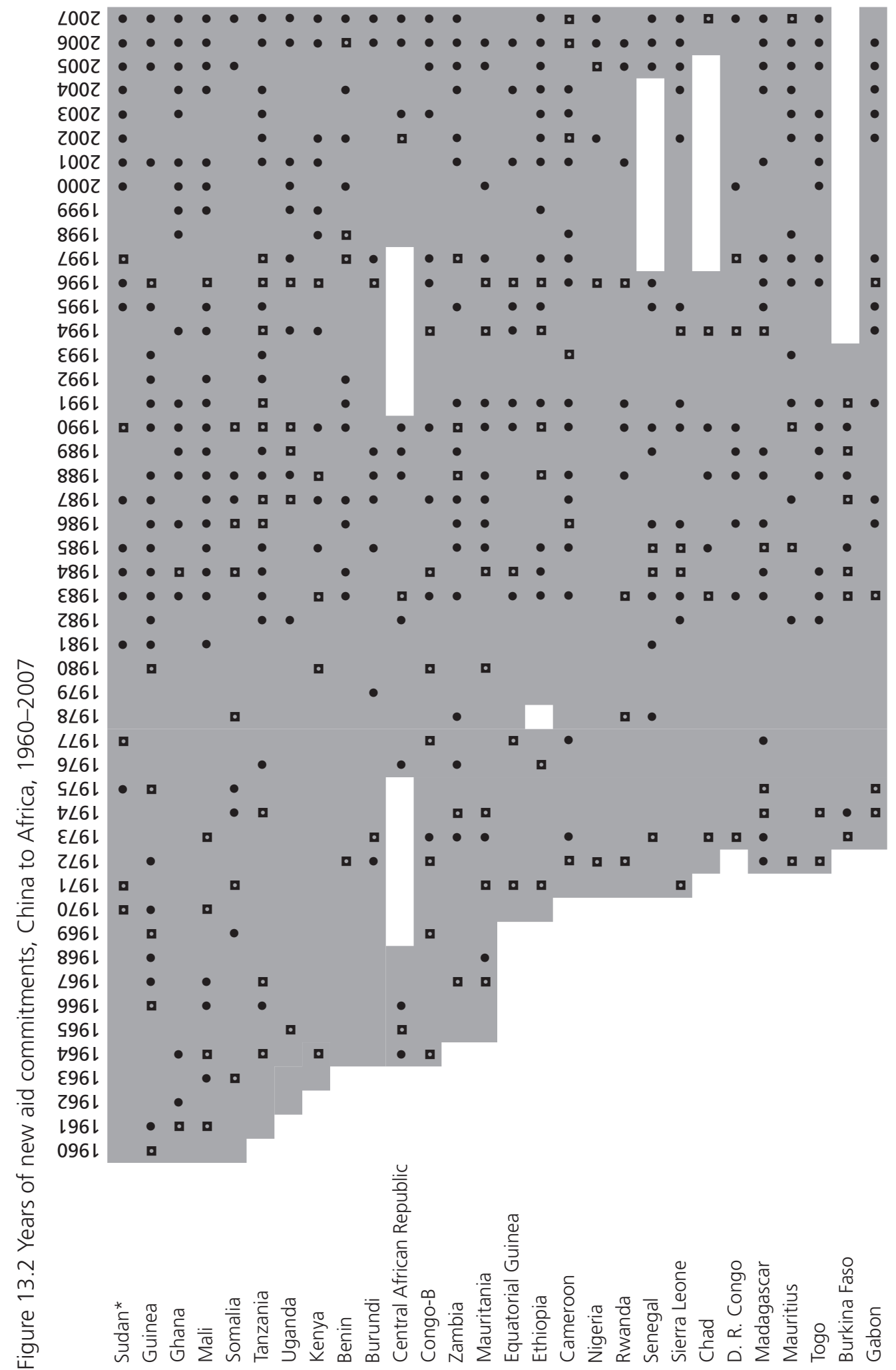


Rising China: Global Challenges and Opportunities

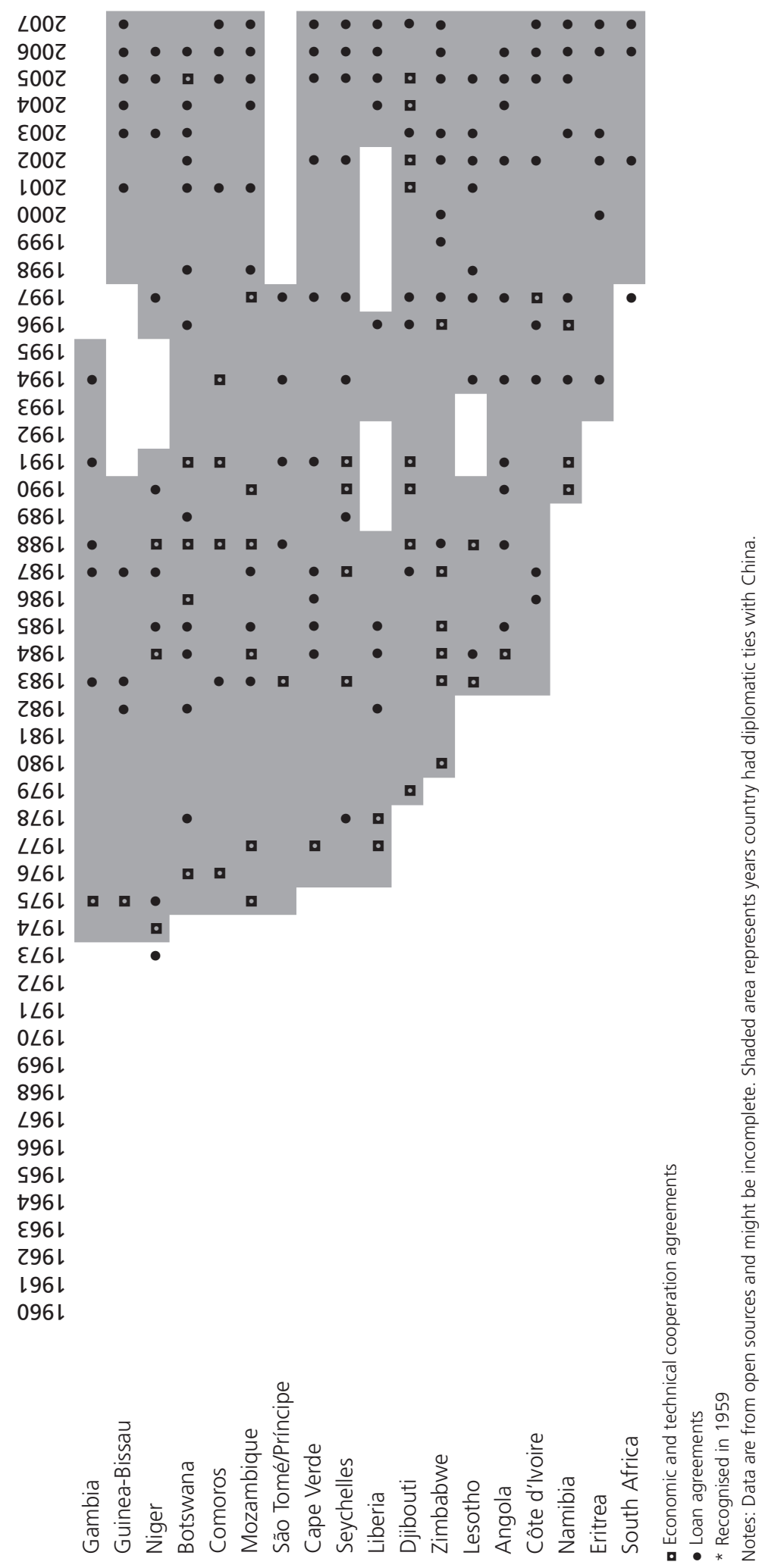


How much aid does China provide to Africa? Close analysis of Chinese budget expenditures, reports and media announcements, supplemented with interviews with Chinese officials, allows us to develop estimates for Chinese aid to Africa (for details, see Brautigam 2011). ${ }^{3}$ Figure 13.3 compares China's official African development aid in 2008 with ODA as reported by some of the major donors.

Figure 13.3 Official development assistance to Africa, 2008

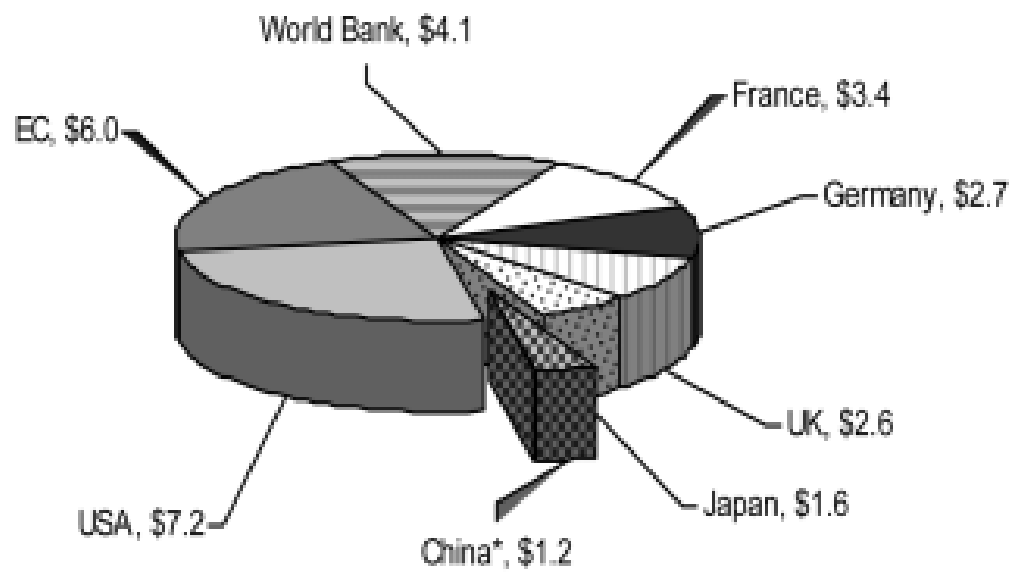

Note: Figures are disbursements. Figures for OECD countries are from the OECD's DAC Statistics. Figures for China are the author's estimates.

Source: Brautigam (2011)

In 2008, China probably disbursed about US\$1.2 billion in ODA in Africa, compared with the World Bank (US\$4.1 billion), the United States (US\$7.2 billion) and France (US\$3.4 billion). China's aid disbursement probably rose to US\$1.4 billion in 2009. These figures, while closer to reality, are far smaller than those estimated by some researchers, or the figures used by other researchers to proxy Chinese aid. What of the fact that in some African countries, the Chinese Government facilitates its companies getting contracts through the provision of large lines of export credit at competitive (but still commercial) rates, much as Japan did in China in an earlier era (Brautigam 2011)? What should we make of these other instruments of Chinese engagement and why do they not qualify as ODA?

The next section discusses two of these package deals, illustrating how Chinese finance works, and why it is essential to know the terms of this finance instead of assuming that it all should be considered as 'Chinese aid'. Some of China's large package deals - thought to be financed as ODA - are in fact more complicated. 


\section{Case studies: Ghana and the Democratic Republic of the Congo}

\section{Ghana's Bui Dam}

In 2007, Sinohydro began construction on the Bui Dam, one of the Ghanaian Government's priority projects. The environmentally controversial $400 \mathrm{MW}$ dam was financed by two separately negotiated China Eximbank loans. One was a commercial export buyers' credit of US\$292 million with 12 years' maturity, a grace period of five years and an interest rate set at a margin of 1.075 per cent over the prevailing Commercial Interest Reference Rates (CIRR). The other, with a fixed interest rate of 2 per cent, appeared to be either a concessional loan or a preferential export credit, for about US\$270 million (Government of Ghana 2008; Habia 2009). Development Assistance Committee rules recommend that a mixed credit like this be reported separately: 'one for the "soft" loan [ODA] and one for the commercial loan [OOF]' (Ahmad 2008). 'Tied aid' like this is allowed under OECD rules for projects that cannot attract commercial financing, although OECD members would be required to report the offer and its terms so that other OECD members could compete on the same terms if they were so inclined (Brautigam 2010).

Just like some of China Eximbank's larger credits in countries such as Angola, the Bui Dam project finance was a resource-secured loan. In this case, it was guaranteed not through oil or minerals, but through export sales of cocoa beans (Brautigam 2011). Research by James Habia has uncovered further details (Habia 2009). Genertec Corporation of China has a cocoa sales agreement with the Ghana Cocoa Board for up to $40000 \mathrm{Mt}$ of cocoa beans (30 000 main crop; 10000 light crop) annually over the life of the loan - that is, 20 years. In 2008-09, Ghana produced $703000 \mathrm{Mt}$ of cocoa beans. Assuming this was all exported, loan repayment would absorb about 6 per cent. If there was negotiation about the price at which the cocoa will be sold, this has not been made public. In other cases of commodity-secured loans, only the amount was specified in the agreement, not the price. China Eximbank President, Li Ruogu, has stated that his bank uses market prices in repayment arrangements for its commodity-secured lines of credit (Brautigam 2011).

China Eximbank also required Bui Hydropower to have a power purchase agreement with the Electricity Company of Ghana. The net revenue from this will be deposited into an escrow account to help repay the loan. The price for the future electricity was tentatively negotiated to be in a range between US $\$ 0.035$ and US $\$ 0.055$ cents $\mathrm{kW} / \mathrm{h}$ (Habia 2009). According to the World Bank, the average electricity tariff in Africa is much higher - at US\$0.13 per kW/h (World Bank 2011). Although the price appears reasonable now, the details of how the price will be changed over the course of the life of the dam are not transparent (Habia 2009).

This case study illustrates several things. First, it shows how Chinese officials can combine different financial instruments to allow a large project to be financed. Part of the finance might qualify as ODA, but not the entire package. It also gives some insight into the way in which Chinese banks can secure their loans - something that allows them to provide more debt finance than might otherwise be the case. Of course, Ghana will now be using its cocoa bean exports to China in future years to repay its debt. These resources will not be 
available for other needs. Whether this is a good deal or not for the Ghanaians will become clear only when the dam is finished, its social and environmental costs mitigated, and its electricity is generated at a reasonable cost.

\section{Democratic Republic of the Congo: mining and reconstruction}

In 2007, two Chinese engineering firms - China Railway Engineering Corporation and Sinohydro - signed an agreement with the DRC for a massive development package. In the original agreement, Chinese banks were slated to finance two separate lines of credit - US $\$ 3$ billion each - which would be used for the repair and reconstruction of the war-torn country. The credits would be repaid out of the profits of an associated joint venture - a cobalt-copper mine - which would also be financed by Chinese capital. The infrastructure package was later reduced to a single line of credit for US $\$ 3$ billion, under pressure from the DRC's other development partners who were concerned about debt sustainability.

Infrastructure to be financed out of the two lines of credit originally included $3402 \mathrm{~km}$ of paved roads, including an auto-route and bridges connecting the main cities of the DRC (Lubumbashi, Bukavu, Goma, Kisangani) and construction and repair of $450 \mathrm{~km}$ of roads within the capital district of Kinshasa; $3213 \mathrm{~km}$ of railway construction or rehabilitation; construction and equipping of 145 health centres, 31 hospitals, 5000 units of low-cost housing, and two universities. ${ }^{4}$ A later list included rehabilitation of two airports and two electricity distribution systems, and the construction of two hydroelectric dams. ${ }^{5}$

What were the terms of this package? A joint venture, Sicomines, would be set up, held 32 per cent by the Congolese - primarily the state-owned natural resource firm Gécominesand 68 per cent by a Chinese consortium dominated by the two Chinese engineering firms. Profits from Sicomines' mining investment would be used to repay loans financing the costs of developing the mine and the unrelated infrastructure projects.

The cost of the infrastructure line of credit was set at LIBOR plus 100 basis points. The associated copper-cobalt mining joint venture was to be developed at a cost estimated to be about US\$3.2 billion, and financed by a separate package combining a zero-interest shareholder loan (prêt d'actionnaire) extended by the Chinese consortium (US\$1.1 billion), and other finance, from an unspecified source, of US\$2.1 billion at a fixed interest rate of 6.1 per cent. $^{6}$

The donor community was deeply concerned about this venture, and particularly by the initial promise of a sovereign guarantee for all the financing, including the mining venture. As the Congolese Government was asking for cancellation of much of its official debt through the Highly Indebted Poor Countries (HIPC) initiative, this appeared to be a case where a new lender would 'free ride' on the backs of old creditors. In a speech to the National Assembly of the DRC, which had to give its approval to the venture, the Minister of Infrastructure, Public Works and Reconstruction pointed out that the loans 'are not concessional' but that the projects had been appraised with an internal rate of return (IRR) of more than 19 per cent, which provided 'the best possible conditions of sustainability of the debt' (DRC 2008). It later became clear that the contract stipulated that the feasibility 
study - which at that point had not yet been done-would need to demonstrate that the Chinese investors would have an IRR of at least 19 per cent; if not, the deal would need to be adjusted. ${ }^{7}$

After a yearlong stand off, the Chinese and the DRC agreed to remove the sovereign guarantee from the debt associated with the mining project. The DRC's creditors, led by the International Monetary Fund (IMF), agreed that the sovereign guarantee could remain for the US\$3 billion infrastructure component of the package, but not the mining venture, while the DRC agreed to drop any mention of the second tranche of infrastructure credits for US\$3 billion.

A second problem was the non-concessional financing terms. The DRC was not allowed to accept non-concessional financing under the IMF and World Bank's Debt Sustainability Framework (DSF) imposed as a condition of HIPC debt relief. The Chinese consortium agreed that if the bank interest rate on the loan (LIBOR plus 100 basis points) rose higher than the rate of 22 April 2008 (about 4.4 per cent), the Chinese consortium would be responsible for the difference. ${ }^{8}$ With these changes, the IMF announced that the grant element of the US\$3 billion infrastructure financing was in the range of 42-46 per cent (IMF 2010). The IMF's definition of concessional under the DSF requires that any loan to a post-HIPC country have at least a 35 per cent grant element. According to the IMF, the Chinese infrastructure loan would now qualify as 'concessional' by their standard, allowing the HIPC debt to be cancelled.

This calculation of concessionality, however, rested on several assumptions. Most significantly, the IMF assumed a worst-case scenario: the mining venture would not generate any net income for 25 years, interest would be compounded during that time, and then the loan would be repaid by the Government, which had given a sovereign guarantee. ${ }^{9}$ The grant element of 42-46 per cent, which looks a lot like 'aid', even if not technically ODA, depends on this assumption. In other words, this assumption created a 25-year grace period. There is nothing incorrect about this, as the Government's sovereign guarantee would not be put at risk except in the situation where the mining venture was unable to generate any profits, thus not repaying a penny of the infrastructure loan for 25 years. Yet this clearly extraordinary assumption, together with the grant element calculation, creates an impression that the loan is financed under terms so generous that they look like aid. This is simply not the case.

Furthermore, the Congolese had already proposed that the signing bonus of US $\$ 250$ million the Chinese consortium agreed to pay the Government for the mining venture be considered as finance 'au titre d'appui budgétaire' or budget support-analogous to the budget support grants offered by donors (DRC 2008). The IMF agreed to consider the entire signing bonus as part of the calculation of the grant element of the infrastructure package, separating it from the mining venture (IMF 2010). Signing bonuses are a common feature of natural resource extraction projects, but not public works infrastructure projects. Thus, the DRC and its traditional creditors squeezed the complicated Chinese package into categories that were more familiar and acceptable to them. 
Would this loan qualify as ODA under the DAC? Clearly, not, according to the OECD, if we apply the test of concessional intent this is clearly not concessional, since the loan from the Chinese government is based on LIBOR, a commercial interest rate. The grant element for the infrastructure loan comes to 33.8 per cent (assuming 4.4 per cent in interest, 25 years' maturity, no grace period and not including the signing bonus), according to the OECD's Development Cooperation Directorate's grant element calculator (2011). Even this calculation, however, would rest on another heroic assumption: that the 'capped' interest rate of 4.4 per cent should be used rather than the rate of LIBOR plus 100 basis points. The Eximbank rate itself is not capped; it may rise above 4.4 per cent, but the Chinese consortium will absorb the extra cost. This is a business decision, not foreign aid.

Finally, it is clear that in the DRC the Chinese themselves do not regard the commoditysecured loans as 'development aid'. In July 2009, the Chinese embassy in the Congolese capitol, Kinshasa, posted a document listing all of the development aid loans provided by China since 2007: two concessional loans, worth RMB250 million (US\$37 million) and RMB245 million (US\$36 million), for telecommunications projects undertaken by Huawei and CITCC; and RMB120 million (US\$18 million) in three zero-interest loans (Embassy of China 2009).

\section{Why do we sometimes get it so wrong?}

Although there has been an increase in transparency by the Chinese in recent years, official announcements on foreign aid are still few and far between. The Chinese Government does not report its aid or other flows to the DAC - a practice adopted by OECD donors (and even many countries outside the OECD). This has led to several attempts by researchers to estimate Chinese aid through media reports, or to use other, published figures as proxies for aid. Two recent examples illustrate why these efforts can produce misleading results.

\section{Estimating 'aid' through media reports}

A group of researchers at the Congressional Research Service (CRS), the research arm of the US Congress, tried to estimate China's aid through collecting media reports (Lum et al. 2009). First, the researchers assumed that China's aid was disorganised. China 'appears to administer foreign aid in an ad hoc fashion, without a centralised system, foreign aid agency and mission, or regularized funding schedule'. In fact, all of these assumptions are incorrect. As might be expected from a government still enmeshed in five-year plans, China's aid is highly centralised, disbursed according to an annual budget, organised primarily by the Department of Aid to Foreign Countries in the Ministry of Commerce, and committed not in an ad-hoc fashion but according to annual plans and budgets (Brautigam 2011).

Having decided that China's development aid did not fit the model of ODA developed by the OECD, the CRS researchers developed their own broad (and questionable) definition of 'aid' for China: 'Many PRC economic investments abroad can be counted as aid rather than foreign direct investment because they are secured by official bilateral agreements, do not impose real financial risks upon the PRC companies involved, or do not result in Chinese ownership of foreign assets'. The researchers then commissioned a group of students at New York University to scour media reports of all Chinese 'pledges of aid or loans and 
government-sponsored investment projects' and put together a database. This produced a Chinese 'aid' figure of US\$17.96 billion for Africa in 2007. The researchers then produced a series of tables that compared these very large estimates of 'aid' with ODA from the OECD countries.

The CRS approach had two obvious problems. First, given that many of the Chinese companies investing abroad - including its oil companies - are state owned, and that its main banks are also state owned, lumping all of their activities together as 'aid' primarily because of the association with the Government (or because they occur in the developing world) defies both logic and convention. Organisation for Economic Cooperation and Development members have never considered export credits, commercial loans or investment by their own state-owned companies as ODA. As noted above, official flows such as these from governments that do not meet the definition of ODA are reported as 'other official flows' (or OOF).$^{10}$ If the same definition of 'official development assistance' is used for China and for the West, in 2007, China disbursed only about US\$850 million in official development assistance to Africa (Brautigam 2011).

This approach also leads to misleading analysis of the purposes of Chinese aid. For example, having defined 'state-sponsored investment' as 'foreign aid', the researchers then conclude that 'China's foreign aid is driven primarily by the need for natural resources' (2009:5). While it is true that natural resources are a primary driver of Chinese investment in Africa, Chinese development aid is allocated to every country in Africa with whom Beijing has diplomatic ties (Brautigam 2008, 2009). China's aid follows the needs of diplomacy, not natural resources. Second, counting up figures based on media stories requires very careful investigation into their veracity. As Remi Bello, CEO of a political-risk consulting firm focused on Africa, noted: 'Keep in mind that only 2 to 4 per cent of MOUs [memorandums of understanding] lead to projects in Africa' (Zoninsein 2010).

\section{Defining economic cooperation as 'aid'}

Other scholars have fallen into a different trap by using 'foreign economic cooperation' data as a proxy for Chinese aid (Biggeri and Sanfilippo 2009; Sanfilippo 2010). The idea that 'economic cooperation' figures are equivalent to aid can be traced back to as early as 2005 when The Economist stated that China had provided a figure of US\$1.8 billion as its 'development aid' for Africa in 2002 ('Forget Mao, let's do business: China and Africa', The Economist, February 7 2005). This report of an 'official aid figure' was picked up and repeated in several World Bank and IMF publications (Broadman et al. 2006; Wang 2007). Yet the Chinese actually published no official figures for aid in 2002. What they did publish was the figure for foreign economic cooperation in Africa: US\$1.8 billion (Brautigam 2011:179).

What is 'foreign economic cooperation'? The Chinese Government publishes data on foreign economic cooperation annually in several yearbooks, including the China Statistical Yearbook. ${ }^{11}$ According to the official definition, these figures refer to turnover (revenues) for 'projects undertaken by Chinese contractors (project contracting companies)' including '(1) overseas civil engineering construction projects financed by foreign investors; 
(2) overseas projects financed by the Chinese government through its foreign aid programs;

(3) construction projects of Chinese diplomatic missions, trade offices and other institutions stationed abroad' (NBS 2009). In other words, as I have noted elsewhere, these figures include

all the work done by Chinese contractors in Africa, whether the contract is paid by the World Bank, the Africa Development Bank (ADB), an African government, other companies that hire Chinese engineering firms, or the Chinese government itself. Chinese companies win about a quarter of all major World Bank construction contracts in Africa, and a half of those funded by the ADB. It would be like reporting US aid to Africa as the revenues earned across the continent by the giant US contracting firms - Bechtel Corporation, Fluor, or Kellogg, Brown and Root (KBR) - or Swedish aid as the turnover of the Swedish company Skanska. (Brautigam 2011)

Chinese companies began carrying out construction projects in Africa for non-Chinese clients in the late 1970s as part of China's turn towards the market. For example, in 1991, China's news agency, Xinhua, reported that 'African nations receive about USD14 billion in assistance from foreign countries. Chinese companies hope that they can make profits through contracting more projects involving this foreign aid' (Xinhua, 26 February 1991).

In Nigeria, Chinese contractors began winning projects in 1979 (Brautigam 2011:64). Between 2000 and 2008, Chinese engineering companies reported earning a total of US\$6.1 billion in revenues from several hundred projects implemented in Nigeria. ${ }^{12}$ One well-known Chinese contractor had carried out more than two dozen projects for various branches of the Nigerian Government over the past decade. In comparison, China's ODA commitments to Nigeria are relatively small - estimated to total less than US $\$ 220$ million between 2000 and 2008 (or US $\$ 440$ million if a preferential US\$200 million credit for a communications satellite is counted as development assistance). ${ }^{13}$

In further evidence that economic cooperation data should not be seen as 'aid', Chinese companies report economic cooperation contracts in countries where China does not have diplomatic ties and thus does not provide official aid or other finance. In 2007, this included Swaziland, Gambia, Burkina Faso, Central African Republic, and Malawi, with a total of 25 contracts (Ministry of Commerce 2008:218). They also report economic cooperation contracts in wealthy countries. In 2009, Chinese companies earned US\$1.15 billion from economic cooperation in Australia, and US\$520.4 million in Germany (NBS 2010). Chinese companies have implemented billions of dollars worth of economic cooperation projects in resource-rich Algeria, Libya, Saudi Arabia and the United Arab Emirates. Chinese companies work in all of these countries because they are competitive in winning construction contracts, not because they are carrying out aid projects.

Nevertheless, several researchers have begun to use these data on 'foreign economic cooperation' as a substitute for figures on 'aid' (Berthélemy 2009; Bhaumik and Yap Co 2009; Sanfilippo 2010:602). Take a recent paper that purports to examine 'possible synergies' between Chinese FDI and 'the aid strategies of the Chinese government' in Africa (Sanfillipo 2010). This paper uses 'economic cooperation' data as a proxy for aid, and posits that the Chinese Government 'might use provision of international economic cooperation...to foster recipients to use the funds to attract Chinese investors' (Sanfillipo 2010:602). But as noted above, the 'economic cooperation' data refer not to something provided by the Chinese 
Government, but to turnover or revenues earned by Chinese contractors. Although they include revenues from aid-financed contracts, these totals cannot simply be assumed to be equivalent to aid. As the Nigeria case shows, in some countries this could lead to a vast overestimation of the size of China's 'aid'.

It is understandable that researchers would like to understand many things about Chinese aid and that only a cross-national database can enable econometric analysis. But using economic cooperation data as a substitute for 'aid' simply means that the analysis will track where Chinese companies are getting contracts.

\section{Conclusions}

This chapter asked: what is aid, where does China give aid, why does it give aid, and how much aid does it give in Africa? After defining aid as 'official development assistance', the chapter discussed the various economic instruments used by the Chinese Government to foster its national economic interests abroad and to conduct its economic diplomacy. The amount of ODA provided to Africa by China in recent years has grown sharply, but it is still not large. A comparison of this amount with that provided by other donors shows that China is a modest, mid-sized donor, although we can expect that its official aid will continue to increase.

China's economic push to 'go global' is coordinated by many policy instruments, some of which were described above. In this way, China resembles Japan's outward march more than it resembles the experience of the other OECD countries. Chinese banks have developed instruments that they believe can link Africa's riches - its natural resources (agricultural and mineral) - to its development. Because they regard these resources as a source of wealth, they do not offer resource-secured loans at concessional rates. To the Chinese, even resourcepoor countries whose balance sheets might not look good sometimes have untapped capacity to service a future debt, if borrowing goes for productive projects. It remains to be seen whether fears about the sustainability of this debt are borne out. The challenges presented by China's engagement in Africa are large - for African countries, who need to learn how to manage this eager new development partner strategically, and for Africa's traditional partners, who feel as though their efforts to reform governance and economic policy might be losing ground. But all the stakeholders will benefit from a more accurate description of the dimensions of this engagement, and a more realistic and grounded idea of the realities of Chinese development assistance and economic cooperation on the continent.

\section{Bibliography}

Alesina, A. and Dollar, D. 2000, 'Who gives foreign aid to whom and why?', Journal of Economic Growth, vol. 5 (March), pp. 33-63.

Berthélemy, J.-C. 2009, Impact of China's engagement on the sectoral allocation of resources and aid effectiveness in Africa, Paper prepared for African Economic Conference 2009: Fostering Development in an Era of Financial and Economic Crises, United 
Nations Economic Commission for Africa (UNECA), 11-13 November 2009, Addis Ababa, Ethiopia, viewed 19 August 2010, <http://www.uneca.org/aec2009/papers/ AEC2009BackgroundPaper.pdf>

Bhaumik, S. K. and Yap Co, C. 2009, Chinese state's economic cooperation-related investment: an investigation of its direction and some implications for outward investment, William Davidson Institute Working Paper No. 966 (August), University of Michigan, Ann Arbor.

Bloomberg 2011, 'Huawei's 30-billion credit line opens doors in Brazil, Mexico', Businessweek, 24 April 2011, viewed 30 April 2011, <http://www.businessweek.com/ news/2011-04-24/huawei-s-30-billion-china-credit-opens-doors-in-brazil-mexico.html>

Brautigam, D. 2008, China's African Aid: Transatlantic challenges, April, German Marshall Fund of the United States, Washington, DC.

Brautigam, D. 2010, China, Africa, and the international aid architecture, Working Paper No. 107 (April), African Development Bank, Tunis.

Brautigam, D. 2011, The Dragon's Gift: The real story of China in Africa, Oxford University Press, UK.

Broadman, H. with Isik, G., Plaza, S., Ye, X. and Yoshino, Y. 2006, Africa's Silk Road: China and India's new economic frontier, 1 November, The World Bank, Washington, DC.

Democratic Republic of the Congo (DRC) 2008, Contribution of the Minister on the Occasion of the Presentation of the Accords Signed Between the Government of the Democratic Republic of the Congo and the People's Republic of China, 9 May, Ministry of Infrastructures, Public Works, and Reconstruction, Kinshasa.

Embassy of China 2009, Aides au Developpement Chine-RDC, 9 July, Embassy of China in the Democratic Republic of the Congo, Kinshasa.

International Monetary Fund (IMF) n.d., Concessionality Calculator, International Monetary Fund, Washington, DC, viewed March 2010, <http://www.imf.org/external/np/pdr/ conc/calculator/default.aspx>

International Monetary Fund (IMF) 2010, Democratic Republic of the Congo: Staff report for the 2009 Article IV Consultation, request for a three-year arrangement under the Poverty Reduction and Growth Facility, and request for additional interim assistance under the Enhanced Initiative for Heavily Indebted Poor Countries, March 2010, International Monetary Fund, Washington, DC, viewed October 2010, <http://www.imf.org/external/ pubs/ft/scr/2010/cr1088.pdf>

Kim, S. S. 1999, 'China and the United Nations', in E. Economy and M. Oksenberg (eds), China Joins the World: Progress and prospects, Council on Foreign Relations Press, New York.

Kuziemko, I. and Werker, E. 2006, 'How much is a seat on the Security Council worth? Foreign aid and bribery at the United Nations', Journal of Political Economy, vol. 114, no. 5.

Lum, T., Fischer, H., Gomez-Granger, J. and Leland, A. 2009, China's foreign aid activities in Africa, Latin America, and Southeast Asia, 25 February, CRS Report for Congress, Congressional Research Service, Washington, DC. 
Manuela, A. 2010, 'Nigeria secures agreement for refineries', Engineering News-Record, 16 June 2010.

Ministry of Commerce various years, China Commerce Yearbook, Ministry of Commerce, Beijing.

Ministry of Commerce 2008, China Commerce Yearbook 2008, Ministry of Commerce, Beijing.

National Bureau of Statistics (NBS) 2009, China Statistical Yearbook 2009, China Statistics Press, Beijing.

National Bureau of Statistics (NBS) 2010, China Statistical Yearbook 2010, China Statistics Press, Beijing.

Organisation for Economic Cooperation and Development (OECD), n.d., Glossary, Organisation for Economic Cooperation and Development, Paris, viewed 22 May 2009, <www.oecd.org/document/19/0,3343,en_21571361_39494699_39503763_1_1_1_1_,00. html>

Organisation for Economic Cooperation and Development (OECD) 2008a, Is it ODA?, Fact Sheet, November, Organisation for Economic Cooperation and Development, Paris, viewed 6 March 2011, <http://www.oecd.org/dataoecd/21/21/34086975.pdf>

Organisation for Economic Cooperation and Development (OECD) 2008b, Personal email communication with a senior official regarding Ghana credits, 17 November, Data Collections Unit, Statistics and Monitoring Division, Development Cooperation Directorate, Organisation for Economic Cooperation and Development, Paris.

Organisation for Economic Cooperation and Development (OECD) 2010, International Development Statistics: Other official flows, 13 April, Organisation for Economic Cooperation and Development, Paris, viewed 6 March 2011, <http://www.oecd-ilibrary. org/development/data/oecd-international-development-statistics/other-official-flowsoof_data-00075-en;jsessionid=1f4rgdb5f6jo3.delta $>$

Standard \& Poor's 2006. 'Bank Credit Report: Export-Import Bank of China', August 2006.

State Council 2011, China's Foreign Aid, April, Information Office of the State Council, People's Republic of China, Beijing.

Vines, A., Wong, L., Weimer, M. and Campos, I. 2009, Thirst for African Oil: Asian national oil companies in Nigeria and Angola, August, Chatham House, London.

Wang, J.-Y. 2007, What drives China's growing role in Africa?, IMF Working Paper No. 07/211 (August), International Monetary Fund, Washington, DC.

World Bank 2011, Energy in Africa: Overview, The World Bank, Washington, DC, viewed 2 April 2010, <http://go.worldbank.org/ZD42IOATZ0>

Zoninsein, M. 2010, 'Nigeria secures agreement for refineries, Engineering News-Record, 16 June. 


\section{Endnotes}

1. Unless otherwise stated, 'Africa' refers to the entire continent, including North Africa.

2. According to a Ministry of Commerce official (Personal email communication, Ministry of Commerce, Beijing, 3 May 2011), these figures all refer to commitments, not disbursements.

3. Given the rapid increase in Chinese aid on an annual basis, the figures for commitments and disbursements are likely to differ far more for Chinese aid than would be the case for the OECD donors. A Chinese official estimated that, in recent years, China Eximbank's commitments for concessional loans are nearly double the disbursements, while grants and zero-interest loans tend to be disbursed much more rapidly. Annual figures for disbursements and commitments are far closer for the aid controlled by the Ministry of Commerce. For more detail on these estimates and additional figures, see Brautigam (2011).

4. Convention de Collaboration entre la République Démocratique du Congo et le Groupement d'Entreprises Chinoises: China Railway Group Limited, Sinohydro Corporation relative au Developpement d'un Projet Minier et d'un Projet d'infrastructures en République Démocratique du Congo, April 22, 2008.

5. Ibid

6. Ibid

7. Ibid

8. Avenant No. 3 à la Convention de Collaboration Relative au Developpement d'un Projet Minier et d'un Projet d'Infrastructures en République Démocratique du Congo du 22 Avril 2008 - 2009, October.

9. Former IMF Senior Official, Personal email and phone communication, 7 and 11 April 2011. The IMF explained that its calculations assumed: '(i) the mining project does not generate any net income and the government guarantee is invoked after 25 years as provided for under the amended Agreement; (ii) accrued interest is compounded' (IMF 2010). The assumption that the mining project would not generate any net income seemed unrealistic. Assuming the project would generate income as predicted, and using the IMF's concessionality calculator (IMF n.d.), the assumption of a US\$250 million 'grant', no grace period, an interest rate of 4.4 per cent and a 25-year maturity, the author found a grant element of just more than 20 per cent compared with the commercial rates prevailing for the US dollar in March 2011.

10. To elaborate: none of these (curious) qualifiers would make an OECD state-sponsored investment qualify as ODA. For example, official bilateral agreements may provide a pledge that an investment will not be expropriated, but this does not make it into 'aid'. Leaving aside the questionable assumption that statesponsored investment is risk free for Chinese companies, the degree to which a government ameliorates the risks faced by its firms abroad has nothing to do with whether the investment qualifies as ODA. No OECD country counts assistance to its companies for their foreign investment as part of its ODA. Finally, it is true that an 'investment' (a government loan, for example) that does not result in ownership of assets abroad does not qualify as foreign direct investment (FDI), but that does not mean that by default it thus qualifies as 'aid' (unless it meets the strict criteria for ODA). It would simply be counted in 'other official flows'.

11. These data are found in the section on foreign economic cooperation under the subheading 'Total amount of contracts and turnover of China's foreign economic cooperation in 2008 by country/region'. The section on foreign economic cooperation also includes a subsection on overseas foreign direct investment (FDI) by Chinese companies. Several researchers who have referred to or used these data stated that they believed the economic cooperation figures also included the FDI data (World Bank 2008:xiii, 7). It is not clear how that would be the case, given that the figures refer to turnover from contracts. The Yearbook definition does not include FDI as part of these figures, and they are listed separately from the contracts and turnover data under the broad heading of 'Foreign economic cooperation'.

12. This is a simple sum of the turnover reported annually in the China Commerce Yearbooks (1998-2009) (Ministry of Commerce various years) and has not been adjusted for inflation. 
13. Official aid financed two rural telephony projects, a borehole project, anti-malaria program training, bird flu prevention, construction of a hospital, a malaria treatment centre, four primary schools, and 500 volunteers in the South-South Cooperation Program operated by the Food and Agriculture Organisation. Not included in this estimate are the costs of at least 50 Nigerian students studying in China and short-term training programs and study tours for 300 Nigerians in China. Nigeria also received non-concessionary export credits of US $\$ 230$ million for two 335 MW gas power plants in 2002 (Nigerian Government Official, Personal email and phone communication, May 2009). In 2007, China Eximbank offered a US\$500 million preferential export credit, which was not taken up during this period, and thus resulted in no turnover for Chinese companies. Although a large line of resource-backed credit such as we have seen in some other African countries was offered to Nigeria, it was not taken up (Vines et al. 2009). 